\title{
PENGARUH FAKTOR MAKRO EKONOMI TERHADAP KREDIT BERMASALAH PADA BANK UMUM DI INDONESIA
}

\author{
Riko Setya Wijaya \\ FEB UPN “Veteran” Jawa Timur | rikosetyawijaya.80@gmail.com
}

\begin{abstract}
Abstrak: Bank sebagai lembaga keuangan adalah bagian dari faktor penggerak kegiatan perekonomian. Kegiatan-kegiatan lembaga sebagai penyedia dan penyalur dana akan menentukan baik tidaknya perekonomian suatu Negara. Dalam perkembangannya, Industri perbankan merupakan salah satu sumber pembiayaan untuk memenuhi kebutuhan yang diinginkan, ketersediaan kredit perbankan memberikan kemungkinan perusahaan untuk melakukan investasi yang tidak bias dilakukan dengan dana sendiri serta memungkinkan rumah tangga untuk melakukan konsumsi yang lebih baik, Oleh karena itu, penyaluran kredit dengan bentuk pendapatan bunganya menjadi sumber utama pendapatan bank. Penelitian ini bertujuan untuk mengetahui pengaruh faktor makro ekonomi terhadap Non Performing Loan pada bank umum di Indonesia dan untuk mengetahui variabel bebas mana yang berpengaruh paling dominan terhadap Non Performing Loan bank umum di Indonesia. Dalam penelitian ini menggunakan data sekunder yaitu data time series dari tahun 2005 sampai dengan 2019. Analisis yang digunakan dalam penelitian ini adalah regresi linier berganda dan variabel yang digunakan, Kurs Valas (XI), Tingkat Suku Bunga BI Rate (X2) dan Tingkat Inflasi (X3) dan Non Performing Loan (Y) sebagai variabel terikatnya. Hasil dari penelitian ini menunjukkan bahwa, Kurs Valas (XI), Tingkat Suku Bunga BI Rate (X2) dan Tingkat Inflasi (X3) dan Non Performing Loan ( $Y$ ) secara simultan berpengaruh signifikan terhadap Non Performing Loan ( $\mathrm{Y}$ ) Ditunjukkan dengan Fhitung = I5,9|I > Ftabel $=3,59$ Sedangkan secara parsial, variabel, Kurs Valas (XI), dan Tingkat Inflasi (X3) tidak berpengaruh signifikan terhadap Non Performing Loan (Y). Variabel Tingkat Suku Bunga BI Rate (X3) yang paling berpengaruh signifikan terhadap Non Performing Loan ( $Y$ ).
\end{abstract}

Keywords : Non Performing Loan, Kurs Valas, Tingkat Suku Bunga, BI Rate dan Tingkat Inflasi 


\section{Pendahuluan}

Perbankan merupakan urat nadi perekonomian di seluruh negara, tidak terkecuali di Indonesia. Dalam upaya pembangunan ekonomi untuk menuju terciptanya kesejahteraan sosial bagi seluruh rakyat Indonesia maka peran Perbankan Nasional dalam membangun perekonomian merupakan salah satu sektor yang diharapkan berperan aktif dalam menunjang kegiatan pembangunan nasional atau regional. Peran Perbankan diwujudkan dalam fungsi utamanya sebagai lembaga intermediasi atau institusi perantara antara debitor dan kreditor.

Sitompul (2002) menyatakan bahwa bertambahnya kebutuhan akan dana pada saat kerja dipeningkatan laju pembangunan dikarenakan banyaknya ekspansi yang dilakukan oleh pemerintah maupun masyarakat. Dalam keadaan seperti ini,pembiayaan sudah tidak dapat lagi dilakukan atas sumber dana sendiri. Untuk tujuan perluasan usaha tersebut, laba yang dibutuhkan tidak lagi mencukupi biaya pengembangan yang dibutuhkan. Industri perbankan merupakan salah satu sumber pembiayaan untuk memenuhi kebutuhan yang diinginkan. Hal tersebut didukung oleh data dari Badan Koordinasi Penanaman Modal (BKPM) kembali menyampaikan data realisasi investasi periode Triwulan III (JuliSeptember) tahun 2019 yang mencapai Rp 205,7 triliun, meningkat sebesar 18,4\% dibandingkan dengan periode yang sama tahun 2018 yang menunjukkan bahwa peningkatan investasi di Indonesia pada tahun 2019 yang meningkat mencapai 18,4\% dari tahun sebelumnya didorong oleh membaiknya iklim investasi, rekor pertumbuhan ekonomi yang kuat beberapa tahun terakhir, dan peningkatan kredit.

Selain untuk tujuan bisnis, kredit sering kali mempermudah masyarakat untuk memenuhi kebutuhuan konsumtifnya, sejalan dengan pendapat Utari, et. al.(2012) yang mengemukakan bahwa ketersediaan kredit perbankan memberikan kemungkinan perusahaan untuk melakukan investasi yang tidak bias dilakukan dengan dana sendiri serta memungkinkan rumah tangga untuk melakukan konsumsi yang lebih baik.

Sebagai kegiatan pengalokasian dana bank yang paling mendominasi, penyaluran kredit memiliki porsi $70 \%-80 \%$ dari total volume usaha. Oleh karena itu, penyaluran kredit dengan 


\section{Riko Setya Wijaya}

bentuk pendapatan bunganya menjadi sumber utama pendapatan bank (Siamat, 2005 :46). Dengan mempertimbangkan hal tersebut, maka diperlukan pengelolaan kredit yang tepat. Dalam menjalankan usaha penyaluran kredit, bank menghadapi risiko kredit, yang didefinisikan sebagai "risiko dimana debitur tidak dapat melunasi hutangnya" (Ghozali, 2007, h. 12).

Seandainya kredit kurang dikelola dengan baik, maka akan banyak terjadi kredit bermasalah (Non PerformingLoan), hal tersebut mengakibatkan pendapatan bunga dan pengembalian pokok kredit menjadi turun yang pada gilirannya bank akan menderita kerugian bahkan kemungkinan terburuknya bank akan mengalami kebangkrutan (Firdaus dan Ariyanti, 2004).

Berikut ini adalah rasio NPL, Kurs, tingkat suku bunga BI Rate,dan Inflasi dari tahun 2016 - 2019.:

Tabel 1.1

Rasio NPL Bank Umum, GDP, Tingkat Suku Bunga,

Nilai Tukar

\begin{tabular}{|c|c|c|c|c|}
\hline Tahun & $\begin{array}{c}\text { NPL } \\
(\%)\end{array}$ & $\begin{array}{c}\text { Kurs } \\
\text { Valas } \\
(\text { Rupiah })\end{array}$ & $\begin{array}{c}\text { Tingkat Suku } \\
\text { Bunga BI rate } \\
(\%)\end{array}$ & $\begin{array}{c}\text { Inflasi } \\
(\%)\end{array}$ \\
\hline 2016 & 2,02 & 13436 & 4,74 & 3,02 \\
\hline 2017 & 2,07 & 13548 & 4,25 & 3,16 \\
\hline 2018 & 2,08 & 14481 & 6,00 & 3,13 \\
\hline 2019 & 2,06 & 13901 & 5,00 & 2,72 \\
\hline
\end{tabular}

\section{Sumber : Bank Indonesia dan Otoritas Jasa Keuangan}

Tabel 1.1. menunjukkan angka rasio NPL, Kurs, tingkat suku bunga BI Rate, dan nilai tukar yang berfluktuasi. Rasio NPL terbesar terjadi pada tahun 2018 sebesar 2,08 \%. Dan terkecil terjadi pada tahun 2016 tetapi jika di lihat dari data tersebut secara keseluruhan NPL mengalami fluktuatif yang hampir stagnan. Dari tabel tersebut juga dapat diketahui bahwa terjadi fenomena gap pada data Kurs, BI rate dan Inflasi apabila dibandingkan dengan data pada tahun sebelumnya terjadi inkonsistensi ini biasa di lihat pada tabel diatas dimana kurs tertinggi terjadi pada tahun 2018 dan terendah pada tahun 2016, untuk BI Rate terendah terjadi pada tahun 2017 dan terbesar terjadi pada tahun 2018 serta data inflasi terbesar terjadi 
tahun 2017 dan terendah pada tahun 2019.

Meskipun rasio NPL (Non Performing Loan) pada bank umum konvensional pada tahun 2005-2019 menunjukkan angka rata-rata di bawah 5\% sesuai ketetapan BI, namun perlu dilakukan pengkajian lebih dalam mengenai kredit bermasalah. Ini dikarenakan pemantauan berkala kualitas kredit, dengan early warning system mampu memperingatkan pihak berwenang mengenai potensi stres perbankan, hal tersebut penting untuk memastikan system keuangan yang sehat dan mencegah krisis sistemik (Bofondi \& Ropele, 2011 :15). Variabel makroekonomi yang terjadi dalam perekonomian suatu negara yang terbukti memengaruhi tingkat NPL yang terjadi di perbankan. Perubahan pada perkembangan indikator variabel makroekonomi akan memengaruhi tingkat NPL kredit perbankan di Indonesia. Oleh karena itu, dalam penelitian ini dibahas mengenai bagaimana pengaruh variabel makroekonomi terhadap tingkat NPL kredit perbankan di Indonesia. Hasil akhirnya diharapkan dapat diketahui variabel makroekonomi mana yang paling berpengaruh terhadap tingkat NPL kredit perbankan di Indonesia.

\section{Landasan Teori}

Kata kredit berasal dari bahasa Latin yaitu "Creditus" yang berarti to trust. Dengan demikian kata kredit sudah berkembang ke mana-mana, tetapi dalam tahap apapun dan kemanapun arah perkembangannya, dalam setiap kata "kredit" tetap mengandung unsur "kepercayaan". Walaupun sebenarnya kredit itu tidak hanya sekedar kepercayaan.Kredit juga memiliki pengertian, kredit merupakan suatu fasilitas keuangan yang memungkinkan seseorang atau badan usaha untuk meminjam uang untuk membeli produk dan membayarnya kembali dalam jangka waktu yang ditentukan.

Kredit yang diberikan oleh bank, dimaksudkan untuk memberikan penyediaan uang yang didasarkan atas perjanjian pinjam-meminjam yang dilakukan antara pihak bank sebagai kreditur dengan pihak nasabah/masyarakat sebagai debitur. Dari pengertian itu dapat diketahui bahwa dalam perjanjian kredit diperlukan adanya suatu jaminan yang diberikan pada Bank.

Tujuan kredit dalam pendekatan ekonomi makro tujuan pemberian kredit guna mendapatkan suatu nilai tambah baik bagi nasabah (debitur) maupun bank sebagai kreditur. Bagi nasabah 
sebagai debitur dengan mendapatkan kredit bertujuan untuk mengatasi kesulitan pembiayaan dan meningkatkan usaha dan pendapatan di masa depan. Sedangkan bagi bank sendiri juga diharapkan melalui pemberian kredit akan menghasilkan pendapatan bunga sebagai ganti harga dari pinjaman itu sendiri. Sedangkan dalam pendekatan ekonomi makro pemberian kredit merupakan salah satu instrument untuk menjaga keseimbangan jumlah uang beredar di masyarakat.Terdapat beberapa fungsi kredit dalam hubungannya dalam siklus perekonomian, perdagangan lalu lintas moneter.

Pengertian Bank pada awal dikenalnya adalah meja tempat menukar uang.Lalu pengertian berkembang menjadi tempat penyimpanan uang dan seterusnya.Namun semakin modernnya perkembangan dunia perbankan, maka pengertian bank pun berubah pula. "Secara sederhana bank diartikan sebagai lembaga keuangan yang kegiatan usahanya adalah menghimpun dana dari masyarakat dan menyalurkan kembali dana tersebut ke masyarakat serta memberikan jasa-jasa bank lainnya". (Kasmir, 2004 : 8).

Nilai tukar adalah harga mata uang satu negara dalam satuan mata uang lainnya yang biasa disebut dengan reference currency (Shapiro, 2006). Wikutama (2010) menjelaskan bahwa depresiasi home currency memberikan dampak terhadap pinjaman dalam valuta asing karena nilai pinjaman meningkat secara relatif sesuai dengan penurunan tersebut. Peningkatan jumlah kewajiban akan mengakibatkan penurunan kemampuan debitur dalam menyelesaikan pinjaman, bahkan dalam banyak kasus mengakibatkan peningkatkan NPL.

Menurut Kasmir (2011), suku bunga dapat diartikan sebagai balas jasa yang diberikan oleh bank yang berdasarkan prinsip konvensional kepada nasabah yang membeli atau menjual produknya. Peningkatan tingkat suku bunga akan memperburuk kualitas dari pinjaman, semakin tingginya biaya hutang membuat debitur semakin sulit membayarkan

pinjamannya. Oleh karena itu peningkatan tingkat suku bunga akan meningkatkan tinkat NPL kredit perbankan (Messai \& Jouini, 2013).

Suku bunga bagi suatu bank adalah harga dari komoditi (uang atau dana)yang diperjual belikan oleh bank (Firdaus dan Ariyanti, 2004). Di Indonesia, penentuan suku bunga, baik biaya dana (cost of fund) maupun bunga kredit (lending rate) mengacu pada BI rate. BI 
Rate adalah suku bunga kebijakan yang mencerminkan sikap atau stance kebijakan moneter yang ditetapkan oleh bank Indonesia dan diumumkan kepada publik. Menurut Kasmir (2011), suku bunga dapat diartikan sebagai balas jasa yang diberikan oleh bank yang berdasarkan prinsip konvensional kepada nasabah yang membeli atau menjual produknya. Peningkatan tingkat suku bunga akan memperburuk kualitas dari pinjaman, semakin tingginya biaya hutang membuat debitur semakin sulit membayarkan pinjamannya. Oleh karena itu peningkatan tingkat suku bunga akan meningkatkan tinkat NPL kredit perbankan (Messai \& Jouini, 2013) Inflasi adalah proses kenaikan harga barang- barang secara terus menerus yang berdampak terhadap penurunan daya beli masyarakat karena secara riil tingkat pendapatannya juga menurun dengan asumsi bahwa tingkat pendapatan masyarakat konstan (Mankiw, 2013). Risiko keuangan juga muncul dikarenakan adanya inflasi, apabila terdapat kenaikan inflasi yang tak terduga akan menyebabkan risiko daya beli. Pada saat terjadi inflasi maka akan menyebabkan beban biaya hidup semakin tinggi karena semakin meningkat biaya akibat harga-harga untuk melakukan konsumsi akan meningkat. Sehingga pada saat terjadinya inflasi maka secara riil pendapatan masyarakat dan perusahaan menurun, sehingga akan menjadi kesulitan bagi debitur untuk mengembalikan pinjaman pada bank.

Inflasi adalah proses kenaikan harga barang-barang secara terus menerus yang berdampak terhadap penurunan daya beli masyarakat karena secara riil tingkat pendapatannya juga menurun dengan asumsi bahwa tingkat pendapatan masyarakat konstan (Mankiw, 2013). Risiko keuangan juga muncul dikarenakan adanya inflasi, apabila terdapat kenaikan inflasi yang tak terduga akan menyebabkan risiko daya beli. Pada saat terjadi inflasi maka akan menyebabkan beban biaya hidup semakin tinggi karena semakin meningkat biaya akibat harga-harga untuk melakukan konsumsi akan meningkat. Sehingga pada saat terjadinya inflasi maka secara riil pendapatan masyarakat dan perusahaan menurun, sehingga akan menjadi kesulitan bagi debitur untuk mengembalikan pinjaman pada bank. 


\section{Gambar 1 : Kerangka Konsep Penelitian}

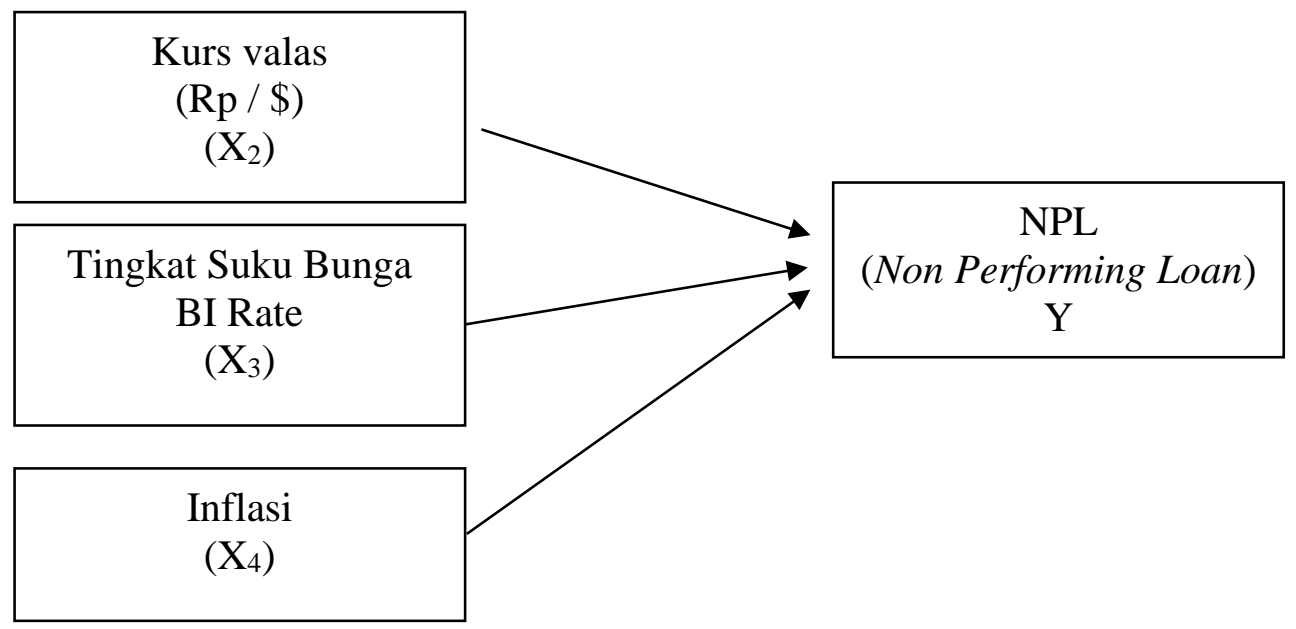

\section{Metode Penelitian}

A. Sampel

Data yang digunakan sebagai sampel dalam penelitian ini adalah data NPL Bank Umum, Kurs, Tingkat Suku Bunga BI Rate dan Tingkat Inflasi. Data ini berbentuk data Tahunan variabel mulai dari tahun 2005 sampai dengan periode tahun 2019,. Alasan pemilihan periode tahun yang digunakan adalah untuk mendapatkan hasil yang lebih akurat sesuai dengan keadaan sekarang ini.

B. Jenis Dan Sumber Data

Jenis data yang digunakan dalam penelitian ini adalah data kuantitatif. Sumber data yang digunakan dalam penelitian ini adalah data sekunder. Data yang digunakan dalam penelitian diperoleh dari otoritas jasa keuangan (OJK), dan Bank Indonesia, badan pusat statistik.

C. Analisis Data

Data yang diperoleh dianalisis dengan analisis regresi linier 
berganda ini menggunakan metode OLS (Ordinary Least Square) dengan bantuan SPSS versi 23.0, dengan model persamaan regresi Linear Berganda adalah sebagai berikut: $\mathrm{Y} 1=\beta 0+\beta 1 \mathrm{X} 1+\beta 2 \mathrm{X} 2+\beta 3 \mathrm{X} 3+\mathrm{e}$

Dimana :

$\mathrm{Y}=$ Npn Performing Loan (NPL)

$\mathrm{X} 1=$ Kurs Valas

X2 = Tingkat Suku Bunga BI Rate

X3 = Tingkat Inflasi

$\beta 0=$ Konstanta (nilai $\mathrm{Y} 1$, apabila X1, X2, X3, =0)

$\beta=$ Koefisien regresi (nilai peningkatan ataupun penurunan)

$\mathrm{e}=$ Variabel Pengganggu

\section{Pembahasan}

Hasil perhitungan tersebut dapat dilihat dalam analisis sebagai berikut :

\begin{tabular}{|c|c|c|c|}
\hline Variabel & $\begin{array}{l}\text { Koefisien } \\
\text { Regresi }\end{array}$ & $\stackrel{t}{\mathrm{t}}$ & $\mathrm{t}$ tabel \\
\hline Kurs Valas $\left(\mathrm{X}_{1}\right)$ & $\begin{array}{c}- \\
0,0000248\end{array}$ & $-0,089$ & 2,201 \\
\hline $\begin{array}{l}\text { Tingkat Suku Bunga BI Rate } \\
\left(\mathrm{X}_{2}\right)\end{array}$ & 1,706 & 3,325 & 2,201 \\
\hline Tingkat Inflasi $\left(X_{3}\right)$ & $-0,162$ & $-0,619$ & 2,201 \\
\hline \multicolumn{4}{|c|}{ Variabel Terikat : Non Performing Loan (NPL) } \\
\hline $\begin{array}{l}\text { Konstan : - 6,334 } \\
=3,59 \\
\text { Koefisien Korelasi (R) : 0,902 }\end{array}$ & \multicolumn{2}{|c|}{$\mathrm{F}$ hitung $=15,911$} & F tabel \\
\hline
\end{tabular}

Dengan melihat hasil regresi yang didapatkan maka peneliti dapat mengambil kesimpulan bahwa untuk Non Performing Loan (NPL) :

\section{Nilai tukar Tidak berpengaruh negatif terhadap non performing} loan (NPL)

Kurs Valas tidak berpengaruh secara nyata (tidak signifikan) terhadap Non Performing Loan (NPL). Hal ini disebabkan karena Kurs tidak berpengaruh nyata (tidak signifikan) terhadap Non Performing Loan Hasil yang diperoleh tersebut menunjukan 
Riko Setya Wijaya

bahwa perubahan kurs tidak mempengaruhi nilai Non Performing Loan yang dimiliki oleh Bank Umum. Hal ini terjadi karena perubahan kurs yang relatif terjadi dalam jangka pendek, sehingga situasi tersebut tidak begitu mengganggu bisnis yang dijalankan nasabah, oleh sebab itu perubahan kurs rupiah tidak mempengaruhi kemampuan nasabah untuk membayar tagihan kredit. Fenomena tersebut mendorong rasio kredit bermasalah yang diukur dengan Non Performing Loan tidak mengalami perubahan berarti akibat adanya perubahan kurs. Hasil yang diperoleh pada tahapan pengujian hipotesis kedua sejalan dengan penelitian Handoko (2011) yang menemukan bahwa kurs tidak berpengaruh signifikan terhadap Non Performing Loan yang dimiliki oleh sebuah bank umum.

\section{Tingkat Suku Bunga BI Rate berpengaruh positif terhadap non performing loan (NPL)}

Tingkat Suku Bunga BI Rate berpengaruh secara nyata (signifikan) terhadap Non Performing Loan (NPL). Hal ini disebabkan bahwa semakin tinggi tingkat suku bunga bank sentral akan mendorong meningkatnya nilai Non Performing Loan yang dimiliki oleh Bank Umum. Hasil penelitian ini sejalan dengan teori yang dijelaskan oleh Dhendawidjaya (2008) tingkat suku bunga merupakan sejumlah keuntungan yang diperoleh bank atau pun nasabah. Bagi bank besarnya tingkat suku bunga kredit tentu akan sangat menentukan laba yang diperoleh oleh sebuah bank, bagi nasabah semakin tinggi tingkat suku bunga bank umum tentu akan mendorong besarnya keuntungan yang diperoleh nasabah. Walaupun demikian ketika tingkat suku bunga tinggi risiko kredit bermasalah menjadi meningkat. Meningkatnya suku bunga akan mendorong jumlah pembayaran kredit yang harus segera dibayarkan menjadi semakin tinggi. Kondisi tersebut terjadi karena ketika tingkat suku bunga dinaikkan menandakan kondisi ekonomi sedang mengalami masalah seperti tingginya inflasi, situasi tersebut tentu berimbas pada sektor usaha yang dikembangkan debitur, peningkatan suku bunga bank sentral tentu bertujuan untuk menarik mata uang lokal yang beredar dimasyarakat, kecenderungan masyarakat tentu akan lebih suka menabung ketika tingkat suku bunga dinaikkan, akan tetapi jika kita amati dalam proses pembayaran kredit, peningkatan suku bunga tentu akan 
mendorong semakin besar nilai tagihan kredit yang akan dipenuhi, situasi tersebut tentu membuat debitur panik serta mempertinggi nilai kredit bermasalah yang terlihat pada rasio Non Performing Loan yang dimiliki oleh bank.

\section{Tingkat Inflasi Tidak berpengaruh negatif terhadap non performing loan (NPL)}

Tingkat Inflasi tidak berpengaruh secara nyata (tidak signifikan) terhadap Non Performing Loan (NPL). Menurut Putong (2002) mengatakan inflasi berdampak kurang menguntungkan dalam perekonomian, menurutnya akibat kepanikan masyarakat menghadapi kenaikan harga barang-barang yang naik terus menerus dan perekonomian tidak berjalan normal (disatu sisi ada masyarakat berlebihan memborong barang sementara yang kekurangan tidak dapat membeli barang), akibatnya negara rentan terhadap segala macam kekacauan yang ditimbulkannya, akibat kepanikan tersebut masyarakat cenderung menarik tabungan guna membeli dan menumpuk barang sehingga banyak bank di rush, akibatnya bank kekurangan dana dan berdampak pada penutupan bank (bangkrut) atau rendahnya dana investasi yang ada.

\section{Penutup}

\section{Kesimpulan}

Kurs Valas tidak berpengaruh secara nyata (tidak signifikan) terhadap Non Performing Loan (NPL), Tingkat Suku Bunga BI Rate berpengaruh secara nyata (signifikan) terhadap Non Performing Loan (NPL), Tingkat Inflasi tidak berpengaruh secara nyata (tidak signifikan) terhadap Non Performing Loan (NPL).

\section{Saran}

Untuk penelitian selanjutnya disarankan tetap menggunakan variabel dalam penelitian ini dan menambahkan variabel makro ekonomi yaitu income per kapita dan variabel fundamental yaitu CAR.

\section{Daftar Referensi}

Abidin, dkk, 2006, "Kinerja Efisiensi Pada Bank Umum", Penerbit STIE, Perbanas, Jakarta. 
,2018, "Statistik Ekonomi Keuangan Indonesia", Bank Indonesia, Surabaya

Arifin, Imamul, 2007. Membuka Cakrawala Ekonomi.PT Setia Purna Inves, Bandung

Case, Karl E dan Ray C Fair, 2004. Prinsip - prinsip Ekonomi Makro. Edisi Kelima, Cetakan Kesatu. Jkarta : PT Indeks

Eachern, William. A. Mc. 2000. Ekonomi Makro : Pendekatan Temporer Terjemahaan. Jakarta : Salemba Empat

Gujarati, 2010, Ekonometrika Dasar, Penerbit Erlangga, Jakarta.

Hasibun, Malayu, 2002, "Dasar - Dasar Perbankan", Edisi Kedua, Penerbit PT. Bumi Aksara, Jakarta.

Herman, 2005, Analisis Penentuan Biaya Dana pada Bank Umum Pemerintah, Penerbit Universitas Gunadarma. Jurnal Ekonomi.

Kasmir, 2002, Bank Dan Lembaga Keuangan Lainnya, Penerbit Raja Grafindo Persada, Jakarta.

,2004, "Pemasaran Bank", Edisi Pertama, Penerbit Prenada Media, Jakarta.

Lukman, Dendawijaya, 2003. Manajemen Perbankan. Cetakan Pertama. Jakarta : Ghalia Indonesia

Manurung, Mandala, 2004, "Uang, Perbankan dan Ekonomi Moneter (Kajian Konsektual Indonesia)", Penerbit FE UI, Jakarta.

Mishkin, Federic S. 2001. Ekonomi Uang, Perbankan, dan Pasar Keuangan, Buku 2 Edisi 8. Jakarta : LPFEUL. Penerbit: Fakultas Ekonomi Universitas Indonesia.

Nachrowi, D. N, dan Usman, Hardius, 2005. Ekonometrika Untuk Analisis Ekonomi dan Keuangan, Jakarta: LPFEUL. Penerbit: Fakultas Ekonomi Universitas Indonesia.

Nopirin, 2000. Ekonomi Moneter, Edisi Pertama, Cetakan Kesepuluh, Buku Kedua, Penerbit BPFE UGM, Yogyakarta. 
Prasetiantono, T. A. 2000. Keluar Dari Krisis : Analsis Ekonomi Indonesia. Gramedia Pustaka Utama, Jakarta

Putong, Iskandar, 2003. Pengantar Ilmu Ekonomi Makro dan Mikro. Penerbit Ghalia Indonesia, Jakarta.

Samuel, Paul A. Dan William D. Nordhaus, 2004. Ilmu Makro Ekonomi. Edisi Ketujuhbelas. Jakarta : PT Media Global Edukasi.

Sigid Ahmad (2009) "Analisis Pengaruh Kredit dan Non Performing Loan (NPL) Terhadap Probabilitas Pada Bank Umum Milik Pemerintah.

Siamat, Dahlan. 2004. "Manajemen Lembaga Keuangan", Edisi keempat, Lembaga Penerbit FE UI, Jakarta.

Sinungan, Muchdarsyah, 2002. Uang dan Bank, Edisi Ketiga, Penerbit Rineka Cipta, Jakarta.

Soelistyo, 2001. "Dasar - Dasar Ekonometrika", BPFE UGM, Yogyakarta.

Soebagio, Hermawan "Analisis Faktor - Faktor yang Mempengaruhi Terjadinya Non Performing Loan pada Bank Umum Komersial (Studi Empiris pada Sektor Perbankan di Indonesia)"'. 2005

Subagio, 2005."Analisis Faktor-Faktor yang Mempengaruhi Terjadinya Non Performing Loan (NPL) Pada Bank Umum Komersial"

Sukirno, Sadono, 2002. "Pengantar Teori Makro Ekonomi", Edisi Kedua, Penerbit PT. Raja Grafindo Persada, Jakarta.

Sulaiman, 2004, Analisa Regresi Menggunakan SPSS, penerbit Andi, Yogyakarta.

Suparmoko, M. 2000. Pengantar Ekonomi Makro. Edisi Keenam. Penerbit BPFE UGM. Yogyakarta.

Susilo, Sri Y,dkk, 2000. Bank dan Lembaga Keuangan Lain, Salemba Empat, Jakarta 
Riko Setya Wijaya

Yulita, Anatia. 2014 "Analisis Pengaruh Faktor Makro Ekonomi Terhadap Tingkat Kredit Bermasalah Pada Bank Umum Di Indonesia".

Yulizar D Sanrego (2011) “Pengaruh Variabel Makro Dan Mikro Terhadap NPL Perbankan Konvensional Dan NPF Perbankan Syariah 